\title{
Effects of Sucrose, Maltose and Sorbitol on Callus Growth and Plantlet Regeneration in Phalaenopsis, Doritaenopsis and Neofinetia
}

\author{
M. Obaidul Islam* and Syoichi Ichihashi** \\ Department of Life Science, Aichi University of Education, Hirosawa, Igaya - cho, Kariya $448-8542$
}

\begin{abstract}
Summary
The effects of sucrose, maltose, and sorbitol on callus growth of Phalaenopsis, Doritaenopsis, and Neofinetia were investigated. Calli derived from these three genera, grown on sucrose medium enriched with coconut endosperm, grew rapidly but remained friable and yellowish even after 3 subcultures at 8 -week intervals. Calli of most cultivars, grown on maltose or sorbitol medium, initiated protocorm-like bodies (PLBs) which subsequently developed into plantlets. Regenerated plantlets were normal and healthy in appearance. Calli of a few Phalaenopsis and Neofinetia proliferated into green masses and continued to grow but did not develop either PLBs or plantlets.
\end{abstract}

Key Words: callus, maltose, Phalaenopsis, sorbitol, sucrose.

\section{Introduction}

Flower beauty, rapid growth, ease of seedling production, and control of flowering have made cultivation of Phalaenopsis and Doritaenopsis (hybrid of Phalaenopsis $\mathrm{x}$ Doritis)profitable for Japanese orchid growers. Hence, the two genera are produced in large quantities as potted plants. However, availability of good clones is still a problem for practical production. Unlike Cymbidium, Dendrobium and Cattleya, Phalaenopsis production by clonal propagation is not widespread so that marketing of seedling plants is common. These seedlings express large phenotypic variations and respond differently to the same cultural conditions. For this reason, there is a need for a reliable, effective and rapid clonal propagation method.

After the first attempt at clonal multiplication in vitro by Rotor (1949), many studies on micropropagation of Phalaenopsis were conducted to develop an efficient clonal propagation method. Despite these efforts, micropropagation in Phalaenopsis is not well established commercially. The initial method for clonal propagation of Phalaenopsis by using flower stalk buds (Rotor, 1949) was modified by subsequent workers (Sagawa and Niimoto, 1960; Sagawa, 1961; Urata and Iwanaga, 1965; Scully, 1966; Tse et al., 1971; Intuwong et al., 1972; Reisinger et al., 1976; Arditti et al., 1977; Fu, 1978; Bouriquet et al., 1982; Arditti and Ernst, 1993). A relatively rapid multiplication method of Phalaenopsis

Received; October 7, 1998. Accepted; March 17, 1999.

* Present Address; Faculty of Agriculture, Gifu University, Yanagido, Gifu, 501 - 1193 Japan

** To whom correspondence should be addressed. was by shoot tip culture (Intuwong and Sagawa, 1974), but the excision of shoot tips or axillary buds killed or severely damaged the mother plants. To overcome these difficulties, researchers utilized leaves of plantlet produced through flower stalk culture (Tanaka, 1987), root tips (Tanaka et al. 1976; Kobayashi et al., 1991), lateral buds on the flower stalks (Fu, 1978), segments of detached plantlets derived from lateral buds (Pieper and Zimmer, 1976; Zimmer and Pieper, 1978), internodal section of flower stalks (Homma and Asahira, 1985; Lin, 1986 ), and lateral buds from young flower stalks (Ichihashi, 1992). However, none of these methods proved satisfactory because of poor, slow PLB formation and different responses among hybrids (Tokuhara and Mii, 1993).

A possible method for rapid, economical production of Phalaenopsis is plantlet initiation via callus (Sagawa, 1990a). If callus could be induced readily, remains stable genetically, grows quickly without changing its nature, produces PLBs easily and finally develops to plantlets, it could be an useful method for commercial micropropagation of Phalaenopsis.

Callus of Phalaenopsis which is usually yellow and friable, grows very rapidly in a Sucrose medium and can become embryogenic when subcultured in a medium supplemented with liquid coconut endosperm (CE) but without sucrose (Sagawa, 1990b). Our calli on sucrosefree medium turned green with age and initiated PLBs, which subsequently developed into plantlets (unpublished data). Calli exposed to maltose and sorbitol responded differently, compared to sucrose (Ichihashi and Hiraiwa, 1996; Islam et al., 1997). Similar results also reported in Neofinetia (Niimi et al., 1995).

Those results indicated the importance of carbon 
sources for callus growth and subsequent PLB initiation. Our objective was to evaluate the effects of sucrose, maltose, and sorbitol on callus growth, PLB initiation, and subsequent plantlet regeneration in Phalaenopsis, Doritaenopsis, and Neofinetia.

\section{Materials and Methods}

\section{Preparation of calli}

Calli of 10 cultivars of Phalaenopsis, Doritaenopsis, and Neofinetia (Table 1) were obtained by culturing

a. Source callus
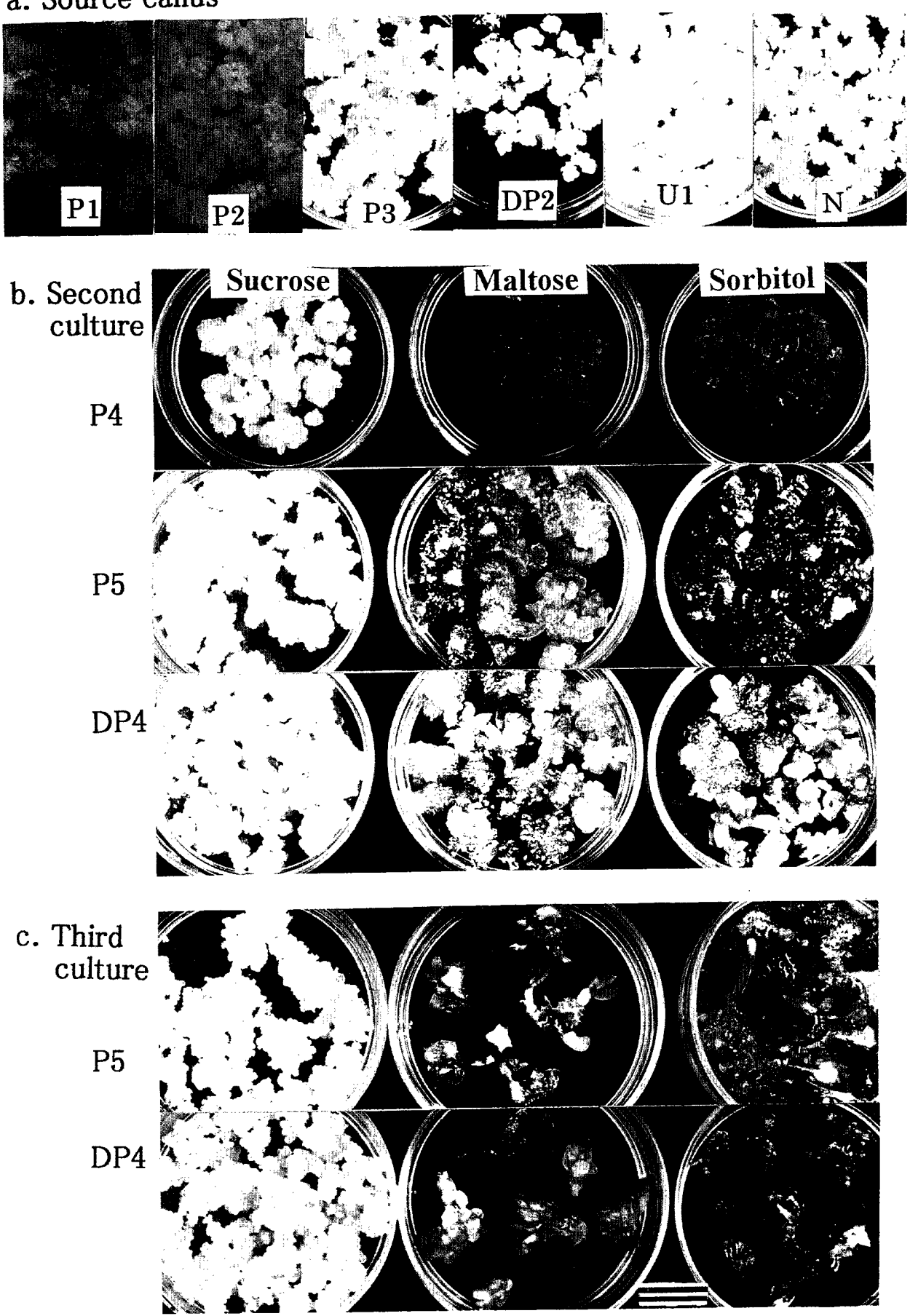

Fig. 1. Calli and their growth patterns on different medium. Scale bar $=1 \mathrm{~cm}$. Cultivars code refer to Table 1 .

a. Callus of Phalaenopsis, Doritaenopsis, and Neofinetia used as the source of plant material. Callus is friable, translucent and white to yellowish.

b. Calli on Sucrose, Maltose and Sorbitol media derived from Phalaenopsis and Doritaenopsis on $10 \mathrm{ml}$ of NP medium in 2nd culture. Callus, $0.1 \mathrm{~g}$, was subcultured from 1st culture for 8 week. PLB developed on maltose and sorbitol media but not on sucrose.

c. Calli cultured on Sucrose, Maltose and Sorbitol media in the 3rd culture. Calli were subcultured three times at 8-week intervals on $10 \mathrm{ml}$ of medium. Plantlets developed on Maltose and Sorbitol media but not on the Sucrose medium. 
Table 1. Source of callus used in this studies.

\begin{tabular}{clc}
\hline \hline Code & Cultivars from which callus was induced & Origin \\
\hline P1 & Phalanopsis Hanaboushi & Dogashima Orchid Center" \\
P2 & Phal. Musashino & $"$ \\
P3 & Phal. Snow Parade & $"$ \\
P4 & Phal. Wedding Promenade & $"$ \\
P5 & Phal. Hanaboushi $\times$ Phal. equestris 'Ilocos' & " \\
P7 & Phal. (Grand City $\times$ Texas Thunder) $\times$ Phal. (Mikawa White $\times$ Wataboushi) & Selected in PLB culture \\
Dp2 & Doritaenopsis New Toyohashi 'No. 451' & Dogashima Orchid Center" \\
Dp4 & Dtps. Hamakita Rainbow $\times$ Phal. Arai 'A - nine' & " \\
U1 & Unknown & University of Hawaii \\
N & Neofinetia falcata & Selected in protocorm culture \\
\hline
\end{tabular}

"Donor: Mr. Ken Tokuhara, " Donor: Dr. Yoneo Sagawa.

flower stalk buds (P7)(Ichihashi, 1992), clonal calli P1 P5, Dp1, Dp2 (Dogashima Orchid Center) and U1 (University of Hawaii) or embryo (N). These calli were selected from callus-like tissue attached to the basal part of PLBs during subculture. Established callus have been maintained by continuous subculturing every 4 weeks on Phalaenopsis medium (P)(Ichihashi and Hiraiwa, 1996) or New Phalaenopsis medium (NP)(Ichihashi, 1992) supplemented with $20 \mathrm{~g} \cdot$ liter $^{-1}$ of sucrose and $100 \mathrm{ml} \cdot$ liter $^{-1}$ of coconut endosperm for more than 6 years. They are friable, translucent, and yellow (Fig. 1a). For experimental materials, $1.0 \mathrm{~g}$ of callus was subcultured twice on $20 \mathrm{ml}$ of basal medium, supplemented with $20 \mathrm{~g} \cdot \operatorname{liter}^{-1}$ of sucrose but without $\mathrm{CE}$ in $50-\mathrm{ml}$ Erlenmeyer flasks at monthly intervals to obtain homogenous callus.

\section{Culture and media condition}

$\mathrm{NP}$ medium was the basal medium (BM) to which sucrose, sorbitol, or maltose were incorporated, because these carbohydrates affect growth of Phalaenopsis and Doritaenopsis calli (Ichihashi and Hiraiwa, 1996). Equimolar concentration $(0.056 \mathrm{M})$ of sucrose, maltose, or sorbitol and $3 \mathrm{~g} \cdot$ liter $^{-1}$ of Gelrite were added to BM and the $\mathrm{pH}$ was adjusted to $5.6 \pm 0.1$. After dissolving the gelling agent in a hot bath, $10 \mathrm{ml}$ of medium were poured into a $50-\mathrm{ml}$ Erlenmeyer flask. After autoclaving for $15 \mathrm{~min}$ at $115^{\circ} \mathrm{C}\left(1.37 \times 10^{5} \mathrm{~Pa}\right)$, and cooled, calli were introduced and the cultures maintained at 25 $\pm 1{ }^{\circ} \mathrm{C}$ under continuous illumination of about 7.1 $\mu \mathrm{E} \cdot \mathrm{m}^{-2} \cdot \mathrm{s}^{-1}$ at day and $0.431 \mu \mathrm{E} \cdot \mathrm{m}^{-2} \cdot \mathrm{s}^{-1}$ at night provided by fluorescent lamps (FLR40S $\cdot \mathrm{N} / \mathrm{M}$, Toshiba).

In the first culture $0.04 \mathrm{~g}$ of callus was subcultured onto a NP medium containing $0.056 \mathrm{M}$ sucrose (Sucrose medium), maltose (Maltose medium) or sorbitol (Sorbitol medium) and kept for 8 weeks as above. For the second culture $0.1 \mathrm{~g}$ of yellow (Sucrose medium) or green calli (Maltose or Sorbitol medium) from the first cultures were subcultured onto the same, fresh medium for another 8 weeks. For the 3 rd culture $0.1 \mathrm{~g}$ of callus (Sucrose medium) or PLB mass (Maltose or Sorbitol medium) from the 2nd culture was subcultured again for 8 more weeks.

\section{Culture evaluation}

The 1st, 2nd and 3rd callus cultures were weighed and the number of PLBs larger than $2 \mathrm{~mm}$ and regenerated plantlets per flask counted. Each treatment was replicated 10 times.

(g)

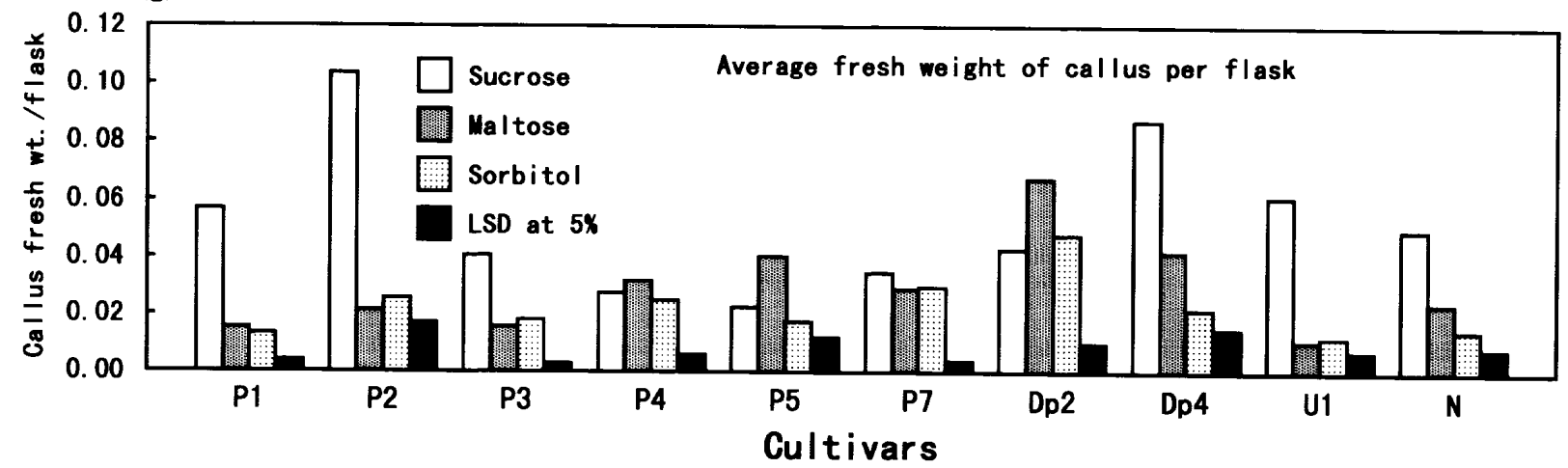

Fig. 2. Calli weight of Phalaenopsis, Doritaenopsis and Neofinetia subcultured on Sucrose, Maltose and Sorbitol media. Callus, $0.04 \mathrm{~g}$, was cultured for 8 weeks (1st culture) in 10 replications on $20-\mathrm{ml} \mathrm{NP}$ medium containing sucrose, maltose or sorbitol. Cultivars code refer to Table 1. 


\section{Results}

\section{First culture}

Phalaenopsis, Doritaenopsis, and Neofinetia calli utilized sucrose, maltose, and sorbitol as energy sources for growth and development, but each carbohydrate elicited a different response. Calli of P1, P2, P3, P7, $\mathrm{Dp} 4, \mathrm{U} 1$, and $\mathrm{N}$ grew significantly faster on Sucrose medium during the first 8 weeks (Fig. 2), whereas calli of P4, P5, and Dp2 grew faster on Maltose medium than they did on Sucrose and Sorbitol media. Among these cultivars, callus proliferation rate was faster in P2 followed by Dp4 and Dp2. Calli on Sucrose medium remained friable, bright yellow and translucent, whereas those on Maltose or Sorbitol medium turned green after 8 weeks.

\section{Second culture}

The $0.1 \mathrm{~g}$ of callus from $1 \mathrm{st}$ culture which were subcultured on Sucrose medium for 8 weeks remained friable, bright yellow, and translucent; it looked similar to the initial callus (Fig. 1b). In almost all cultivars, the increase of fresh weight during PLB development was significantly smaller on Sorbitol and Maltose media than that on Sucrose medium; calli P5 and P7 responded
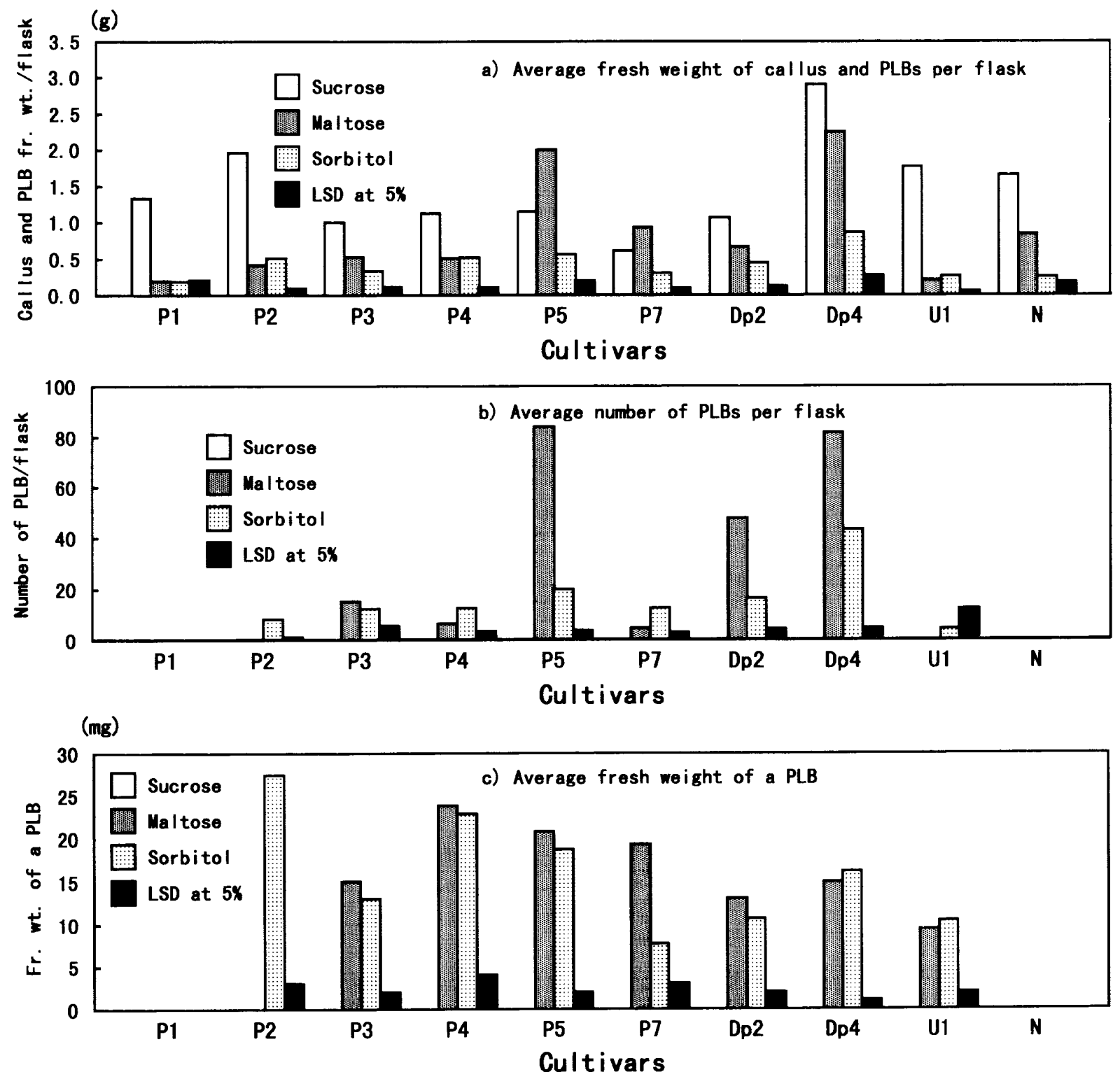

Fig. 3. Calli and PLB yields of Phalaenopsis, Doritaenopsis and Neofinetia cultured on Sucrose, Maltose and Sorbitol media. Proliferated callus in 1 st culture, $0.1 \mathrm{~g}$, was subcultured on fresh $20 \mathrm{ml}$ of medium containing the same carbohydrate and cultured for 8 weeks with 10 replication (2nd culture). Cultivars code refer to Table 1.

a) Average fresh weight of callus and PLB per flask after an 8- week culture on media containing different carbohydrates in the 2 nd culture.

b) Average number of PLBs per flask larger than $2 \mathrm{~mm}$ produced in the $2 \mathrm{nd}$ culture.

c) Average fresh weight of a PLB produced in the 2 nd culture. 
equally well to maltose as sucrose (Fig. 3a).

When green calli on Maltose and Sorbitol media were subcultured onto the same fresh media, they developed to PLBs larger than $2 \mathrm{~mm}$ except for calli P1 and N (Fig. $3 \mathrm{~b})$. These two clones remained green and produced no PLBs larger than $2 \mathrm{~mm}$. Cultivars P2 and U1 developed
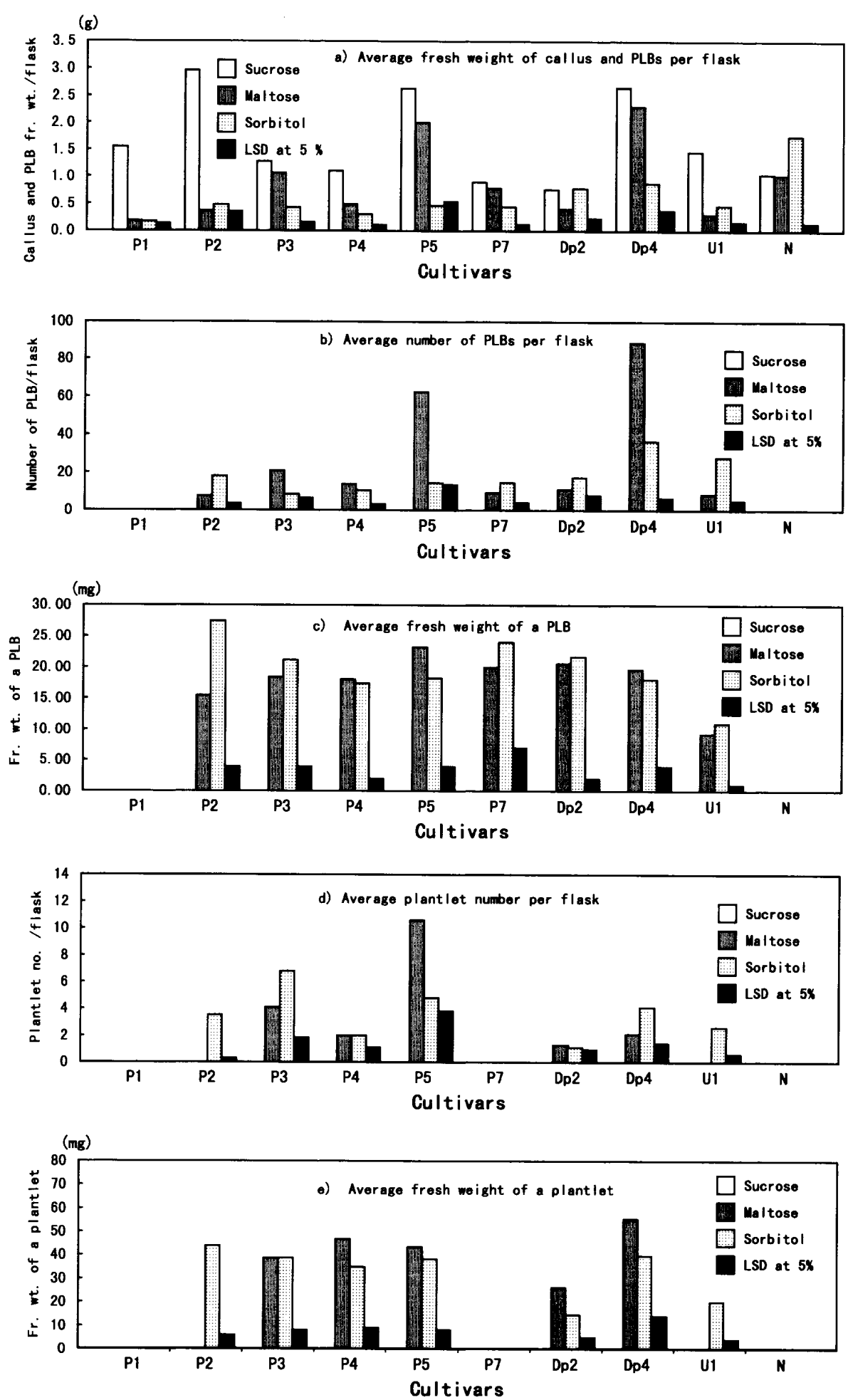

Fig. 4. Yields of calli, PLBs, and plantlets of Phalaenopsis, Doritaenopsis and Neofinetia subcultured on sucrose, maltose and sorbitol for 24 weeks. Calli and PLBs proliferated in 2 nd culture, $0.1 \mathrm{~g}$ was subcultured on fresh medium ( 3 rd culture) containing the same carbohydrate. Cultivars code refer to Table 1.

a) Average fresh weight of calli, PLBs, and plantlets per flask after 8-weeks of culture on media containing different carbohydrates in 3 rd culture.

b) Average number of PLBs larger than $2 \mathrm{~mm}$ per flask produced in the 3rd culture.

c) Average fresh weight of a PLB produced in the 3 rd culture.

d) Average number of plantlets per flask produced in the 3 rd culture.

e) Average fresh weight of a plantlet produced in the 3rd culture. 
a few PLBs larger than $2 \mathrm{~mm}$ only on Sorbitol medium. Significantly more PLBs differentiated on calli P5, Dp2, and Dp4 on maltose than on sorbitol. Clusters of globular or ovate PLBs with a light or dark green tinge developed in most cultivars (Fig. 1b); the PLBs were slender or tubular and differentiated separately in U1. Weight per PLB differed among cultivars (Fig. 3c).

\section{Third culture}

When calli or PLB mass from the 2nd culture were subcultured for 8 more weeks, the calli on Sucrose medium appeared and grew similarly to those of the initial calli and those of the 2nd culture (Fig. 1c, 2, 3c). Although the fresh weight of calli P4, P5, and Dp2 in the 1 st culture increased faster on maltose than on sucrose, Sucrose medium was best for all cultivars except $\mathbf{N}$ in the 3 rd culture (Fig. 4a).

When PLBs, which developed in the 2nd culture on Maltose and Sorbitol media, were subcultured, all, except P1 and N, grew and multiplied (Fig. 4b). P1 and $\mathrm{N}$ produced no PLB. PLBs of P3, P5, and Dp4 multiplied best on maltose, whereas those of P2, P7, and U1 did equally well on sorbitol.

PLBs of P3, P4, P5, Dp2, and Dp4, subcultured on Maltose medium, regenerated plantlets (Fig. 4d); those of $\mathrm{P} 2$ and $\mathrm{U} 1$ grew into plantlets only on Sorbitol medium (Fig. 4d, 4e). Green calli mass of P1 and N from the 1st culture continued to proliferate for the duration of the experiment; they failed to differentiate PLBs (Fig. 4b). PLB of P5 on maltose had the highest frequency of plantlets regeneration in the 3 rd culture, followed by P3 on sorbitol (Fig. 4d); the remainder, except $\mathrm{P} 1, \mathrm{P} 7$, and $\mathrm{N}$ regenerated plantlets on maltose and/or sorbitol, but fewer than did those of P5 and P3. Plantlet development from PLB on Maltose medium was accompanied by the formation of additional PLBs, but a few or no PLB was initiated on Sorbitol medium (Fig. $1 \mathrm{c}, 4 \mathrm{~b}$ ). Plantlets of P4, P5, Dp2, and Dp4 grew best on maltose. The final weight of $\mathrm{P} 3$ plantlets grown on maltose and sorbitol were nearly the same (Fig. 4e).

\section{Discussion}

Calli used in this experiment were induced before 1991 and were maintained for more than 6 years on P or NP media containing coconut endosperm (CE). When they were subcultured at 4-week intervals, they proliferated very fast. The multiplication rates for 8 weeks on NP medium with sucrose but without CE ranges between 5.6 fold (P5; 0.223/0.04) and 26.0 fold (P2; 1.04/ 0.04, Fig. 2). The min/max values interpolated on an annual multiplication rate are equivalent to 73.5 $\mathrm{x} 10^{3}$ and $1.648 \times 10^{6}$ fold, respectively. Although these values are enough for mass rapid clonal multiplication, the rate could be improved by modification of the media (Ichihashi and Islam, 1999).

As for plantlet formation, estimated number of plantlets produced from $0.04 \mathrm{~g}$ of callus for 24 weeks were
33.7 (P3), 32.0 (P4), 852.2 (P5), 57.5 (Dp2), and 197.5 (Dp4). These rates vary, but are rapid enough for commercial plantlet production. However, P1, P7, and N produced no plantlets. They developed only green callus. Thus, plantlet formation from these calli remain a problem.

Most of our calli developed PLBs and subsequently plantlets on Maltose medium or Sorbitol medium, but not on Sucrose medium. Some cultivars developed PLB and plantlets only on Sorbitol medium, whereas several did not. Phalaenopsis callus on modified Vacin and Went medium without sucrose and with CE turned green and formed embryoids and plantlets (Sagawa, 1990a, 1990b). Callus color and growth in Phalaenopsis and related genera were affected by the carbohydrate utilized. Some calli turned green and grew slowly on a medium containing no carbohydrate (Ichihashi and Hiraiwa, 1996), whereas old calli without subculturing also turned green but formed PLBs (unpublished data). These results indicate that sucrose should be eliminated from a culture medium and maltose or sorbitol substituted for most cultivars for optimal plantlet regeneration.

A wide variety of sugars may act as a carbon source for germinating seeds and young seedling. Some hybrid and species show preferences for specific sugars (Arditti, 1967; Arditti and Ernst, 1984). But in this experiment cultivars P4, P5, and Dp2 multiplied better in a maltose medium than with sucrose. Likewise some tissues of vandaceous orchids proliferated best in sucrose-free CE-supplemented medium (Kunisaki et al., 1972; Teo et al., 1973; Teo and Wong, 1978). Phalaenopsis callus grew best on a medium containing both sorbitol and CE (Ichihashi and Hiraiwa, 1996). Hence, for callus proliferation and subsequent plantlet regeneration, selection of the carbon source is important.

We observed greening of callus commonly on Maltose or Sorbitol medium, but PLB and plantlet differentiation was restricted only to green callus of some cultivars. Greening of Phalaenopsis PLBs was also enhanced in the absence of sucrose from the culture medium (Intuwong and Sagawa, 1974). Fructose affected not only callus growth but also chlorophyll content and PLB development in Aranda Tay Swee Eng (Chia et al., 1988). We found that calli of Phalaenopsis, Doritaenopsis, and Neofinetia proliferated without organogenesis and chlorophyll formation in a sucrose medium; these calli developed PLB and subsequently plantlets on maltose and/or sorbitol media. Similar results were reported in callus of Neofinetia falcata (Niimi et al., 1995).

Sucrose is added to a culture medium as energy source so that tissues require no photosynthetic activity for their growth. However, sucrose serves not only as energy source but it also controls other factors. Its elimination and replacement by maltose and sorbitol induced chlorophyll and PLB differentiation.

Hence, the type of carbohydrate supplied to cells and 
callus cultures affects morphological changes. Sugars affect sugar-sensing systems that initiate changes in gene expression for photosynthesis, reserve mobilization, and export process (Koch, 1996). The greening of callus may be another expression of genes relating to photosynthesis via the sugar-sensing system.

In tissue culture of some plants, the type and concentration of carbohydrates are important for inducing somatic embryos (Kunitake and Mii, 1998) as we found with the development of PLBs from callus in Phalaenopsis. The physiological/biochemical bases are not clear, but we have illustrated that different carbohydrates do affect morphological changes of Phalaenopsis callus.

Somaclonal variation of micropropagated plantlets is a major concern in micropropagation. Although callus culture can lead to somaclonal variations (Tokuhara and Mii, 1998) and also production of normal flowers (Ishii et al., 1998), we have not yet encountered such results. However, according to our preliminary investigations, chromosomal aberration (unpublished data) is suspected in P1 and P7 which did not form PLBs.

Further investigations are required to confirm the risk of somaclonal variations of callus derived plantlets. The most relevant point in this experiment was the PLB and/or plantlet induction from callus, although none was regenerated in P1, P7, and N. In some other cultivars the plantlet formation rate was not high. These finding may form the basis of practical methods for the rapid, stable production of plantlets via callus culture in Phalaenopsis, Doritaenopsis, and Neofinetia.

\section{Acknowledgement}

We thank Dr. Joseph Arditti, Professor of University of California, Irvine, for commenting and reading the manuscript. We also thank Dr. Yoneo Sagawa, Professor of University of Hawaii, Manoa and Mr. Ken Tokuhara, Dogashima Orchid Center, for the gifts of calli.

\section{Literature Cited}

Arditti, J. 1967. Factors affecting the germination of orchid seeds. Bot. Rev. 33: 19-20.

Arditti, J., E. A. Ball and D.M. Reisinger. 1977. Culture of flower-stalk buds: A method for vegetative propagation of Phalaenopsis. Amer. Orchid Soc. Bull. 46: 236-240.

Arditti, J. and R. Ernest. 1984. Physiology of germinating orchid seeds. p. 179-224. In: J. Arditti (ed.). Orchid biology - reviews and perspectives. Vol. 3. Cornell Univ. Press, Ithaca, N.Y.

Arditti, J. and R. Ernest. 1993. Micropropagation of orchids. John Willey \& Sons, Inc., N.Y.

Bouriquet, R., H. Broly and B. Legrand. 1982. Clonal propagation of Phalaenopsis (Orchidaceae) by in vitro culture. p. 35-38. In: Early and Demarly (eds.). Variability in plants regenerated from tissue culture. Praeger, New York,
Chia, Y. K., C. S. Hew and C. S. Loh. 1988. Carbon/nitrogen ratio and greening and protocorm formation in orchid callus tissue. Hort. Sci. 23: 599-601.

Fu, F. M. L. 1978. Studies on the tissue culture of orchid. 1. Clonal propagation of Phalaenopsis by lateral buds from flower stems. Orchid Rev. 87: 308-310.

Homma, Y. and T. Asahira. 1985. New means of Phalaenopsis propagation with internodal sections of flower stalk. J. Japan. Soc. Hort. Sci. 53: 379 - 387.

Ichihashi, S. 1992. Micropropagation of Phalaenopsis through the culture of lateral buds from young flower stalks. Lindleyana 7: 208-215.

Ichihashi, S. and H. Hiraiwa. 1996. Effects of solidifiers, coconut water, and carbohydrates source on growth of embryogenic callus in Phalaenopsis and allied genera. J. Orchid Soc. India 10: $81-88$.

Ichihashi, S. and M. O. Islam. 1999. Effects of complex organic additives on callus growth in three orchid genera, Phalaenopsis, Doritaenopsis, and Neofinetia. J. Japan. Soc. Hort. Sci. 68: 269- 274.

Intuwong, O., J. T. Kunisaki and Y. Sagawa. 1972. Vegetative propagation of Phalaenopsis by flower stalk cuttings. Hawaii Orchid J. 1: 13-18.

Intuwong, O. and Y. Sagawa. 1974. Clonal propagation of Phalaenopsis by shoot tip culture. Amer. Orchid Soc. Bull. 54: 893-895.

Ishii, Y., T. Takamura, M. Goi and M. Tanaka. 1998. Callus induction and somatic embryogenesis of Phalaenopsis. Plant Cell Report 17: 446-450.

Islam, M. O., H. Hiraiwa and S. Ichihashi. 1997. Effects of solidifiers, coconut water, and carbohydrates on growth of embryogenic callus of Phalaenopsis. In: S. Ichihashi and H. Inoue (eds.). Proc. Nagoya Intr. Orchid Congress.'97. Nagoya, Japan.

Kobayashi, M., M. Komatuda and S. Yonai. 1990. Studies on the vegetative propagation of Phalaenopsis through root-tip culture. J. Japan. Soc. Hort. Sci. 59 (Suppl. 2): 664- 665 (In Japanese).

Koch, K. E. 1996. Carbohydrate-modulated gene expression in plants. Ann. Rev. Plant Physiol. Plant Mol. Biol. 47: $509-540$.

Kunisaki, J. T., K. K. Kim. and Y. Sagawa. 1972. Shoot tip culture of Vanda. Amer. Orchid Soc. Bull. 41: 435439.

Kunitake, H. and M. Mii. 1998. Somatic embryogenesis and its application for breeding and micropropagation in Asparagus (Asparagus officinalis L.). Plant Biotechnology 15: $51-61$.

Lin, C. C. 1986. In vitro culture of flower stalk internodes of Phalaenopsis and Doritaenopsis. Lindleyana 1: 158163.

Niimi, Y., C. Akaza and Y. Hayata. 1995. Organogenesis and plant regeneration from callus cultures in Neofinetia falcata. p. 81-90. In: S. Ichihashi and H. Inoue (eds.). Proc. Nagoya Intr. Orchid Congress.'95. Nagoya, Japan

Pieper, W. and K. Zimmer. 1976. Clonal propagation of 
Phalaenopsis in vitro. Acta Hort. 64: 21-23.

Reisinger, D. M., E. A. Ball and J. Arditti. 1976. Clonal propagation of Phalaenopsis by means of flower-stalk node culture. Amer. Orchid Soc. Bull. 45: 45-52.

Rotor, G. 1949. A method of vegetative propagation of Phalaenopsis species and hybrids. Amer. Orchid Soc. Bull. 18: 738-739.

Sagawa, Y. 1961. Vegetative propagation of Phalaenopsis by stem cuttings. Amer. Orchid Soc. Bull. 30: 808-809.

Sagawa, Y. 1990a. Orchids, other considerations. p. 638 653. In: P. V. Ammirato, D. A. Evans, W. R. Sharp and Y. P. S. Bajaj (eds.). Handbook of plant cell culture Vol.5. McGraw - Hill Pub. Co., New York.

Sagawa, Y. 1990b. Biotechnology in orchids. p. 46-48. In: T. Kimura, S. Ichihashi and H. Nagata (eds.). Proc. Nagoya Intr. Orchid Congress.'90. Nagoya, Japan.

Sagawa, Y. and D. Niimoto. 1960. Vegetative propagation of Phalaenopsis. Fla. Orchidist 3: 22.

Scully, R. M. 1966. Stem propagation of Phalaenopsis. Amer. Orchid Soc. Bull. 35: 40-42.

Tanaka, M., Y. Senda and A. Hasegawa. 1976. Plantlet formation by root tip culture in Phalaenopsis. Amer. Orchid Soc. Bull. 56: 1024-1222.

Tanaka, M. 1987. Studies on the clonal propagation of
Phalaenopsis through in vitro culture. Mem. Fac. Agric. Kagawa Univ. 49: 1-85.

Teo, C. K. H., J. T. Kunisaki and Y. Sagawa. 1973. Clonal propagation of strap-leafed Vanda by shoot tip culture. Amer. Orchid Soc. Bull. 42: 402-405.

Teo, C. K. H. and C. H. Wong. 1978. Effect of sucrose on the growth of protocorms of Holttumara Loke Tuck Yip. Orchid Rev. 86: 285-289.

Tokuhara, K. and M. Mii. 1993. Micropropagation of Phalaenopsis and Doritaenopsis by culturing shoot tips of flower stalk buds. Plant Cell Rep. 13: 7-11.

Tokuhara, K. and M. Mii. 1998. Somaclonal variations in flower and inflorescence axis in micropropagated plants through flower stalk bud culture of Phalaenopsis and Doritaenopsis. Plant Biotechnology. 15: 23-28.

Tse, A. T., R. J. Smith and W. P. Hacektt. 1971. Adventitious shoot formation on Phalaenopsis nodes. Amer. Orchid Soc. Bull. 40: 807-810.

Urata, U. and E. T. Iwanaga. 1965. The use of Ito-type vials for vegetative propagation of Phalaenopsis. Amer. Orchid Soc. Bull. 34: 410-413.

Zimmer, K. and W. Pieper. 1978. Clonal propagation of Phalaenopsis by excised buds. Orchid Rev. 86: 223 227.

$$
\begin{gathered}
\text { ファレノプシス，ドリテノプシス，フウランのカルスの生育と幼植物分化に及ぼすスクロース， } \\
\text { マルトース，ソルビトールの効果 } \\
\text { M. オバイドル イスラム・市橋正一 }
\end{gathered}
$$

愛知教育大学生命科学領域 4488542 刏谷市井ヶ谷町広沢 1

\footnotetext{
摘 要

スクロース, マルトース, ソルビトールがファレノブシス, ドリテノプシス，フウランのカルスの生育と幼植物分化に及 ぼす, 炭素源としての効果について調べた。供試したカルス は黄色のフライアブルなもので，スクロースを添加した培地 では，供試時と同様な性状で良好に増殖した。マルトースあ

るいはソルビトールを添加した培地では，供試力ルスの多く はPLBを形成し，続いて幼植物を分化した，また分化した幼 植物の外観は正常で健全であった。.部のファレノプシスの カルスとフウランのカルスは緑色の細胞塊を形成したが， PLBならびに幼植物は分化しなかった。
} 